\title{
Plasma vitamin D, past chest illness, and risk of future chest illness in chronic spinal cord injury (SCl): a longitudinal observational study
}

\author{
This article has been corrected since Advance Online Publication and a correction is also printed in this issue
}

Kristopher Clark ${ }^{1} \cdot$ Rebekah L. Goldstein $^{2} \cdot$ Jaime E. Hart $^{3} \cdot$ Merilee Teylan $^{2} \cdot$ Antonio A. Lazzari (D), ${ }^{1,4}$ David R. Gagnon ${ }^{5}$ - Carlos G. Tun ${ }^{6}$ • Eric Garshick ${ }^{3,7}$

Received: 14 July 2019 / Revised: 21 December 2019 / Accepted: 23 December 2019 / Published online: 16 January 2020

(c) The Author(s), under exclusive licence to International Spinal Cord Society 2020

\begin{abstract}
Study design Observational study.

Objective Assess associations between vitamin D levels and other risk factors on future chest illness in a chronic spinal cord injury (SCI) cohort.

Setting Veterans Affairs Boston and the Boston, MA community.

Methods Between August 2009 and August 2017, 253 participants with chronic SCI were followed over a median of 3.2 years (up to 7.4 years) with two to four visits a median of 1.7 years apart. At each visit, plasma 25-hydroxyvitamin D level was obtained, spirometry performed, and a respiratory questionnaire assessing chest illnesses since last visit was completed. Repeated measures negative binomial regression was used to assess chest illness risk longitudinally.

Results At entry, $25 \%$ had deficient vitamin D levels ( $<20$ nanograms/milliliter (ng/ml)), 52\% were insufficient $(20$ to $<30 \mathrm{ng} / \mathrm{ml})$, and $23 \%$ were sufficient $(\geq 30 \mathrm{ng} / \mathrm{ml})$. Over 545 study visits, chest illnesses $(n=106)$ were reported by 60 participants. In multivariable models (including previous chest illness history), deficient vitamin D levels (compared with those with sufficient levels) were associated with future chest illness though with wide confidence limits (relative risk $(\mathrm{RR})=1.36,95 \%$ confidence intervals $(\mathrm{CI})=0.74,2.47)$. The strongest association with chest illness during the follow-up period was in persons who reported pneumonia/bronchitis after injury and a chest illness in the three years before study entry $(\mathrm{RR}=7.62 ; 95 \% \mathrm{CI}=3.70,15.71)$. Conclusion Assessed prospectively in chronic SCI, there was a suggestive association between deficient vitamin D levels and future chest illness. Past chest illness history was also strongly associated with future chest illness.
\end{abstract}

\section{Introduction}

Persons with chronic spinal cord injuries (SCI) are at risk for respiratory dysfunction which depends on the extent and

Supplementary information The online version of this article (https:// doi.org/10.1038/s41393-019-0409-7) contains supplementary material, which is available to authorized users.

Eric Garshick

Eric.Garshick@va.gov

1 Department of Medicine, Boston University/Boston Medical Center, Boston, MA, USA

2 Research and Development Service, VA Boston Healthcare System, West Roxbury, MA, USA

3 Channing Division of Network Medicine, Department of Medicine, Brigham and Women's Hospital and Harvard Medical School, Boston, MA, USA completeness of SCI as well as increased morbidity and mortality from chest illnesses [1-4]. Evidence suggests that vitamin $\mathrm{D}$ is an important metabolic factor that influences a variety of cellular processes related to immunity and respiratory health $[5,6]$. Compared with able-bodied persons, chronic SCI is associated with vitamin D deficiency or insufficiency likely due to a variety of factors including poor nutritional intake and lifestyle habits (such as tobacco use,

4 Division of Primary Care and Rheumatology Section, VA Boston Healthcare System, West Roxbury, MA, USA

5 VA Cooperative Studies Program, VA Boston Healthcare System, Boston, MA, USA

6 Department of Physical Medicine and Rehabilitation, VA Boston Healthcare System, Boston, MA, USA

7 Pulmonary, Allergy, Sleep and Critical Care Medicine Section, VA Boston Healthcare System and Harvard Medical School, West Roxbury, MA, USA 
reduced exposure to sun light, or decreased exercise) [7, 8]. Several observational and cohort studies further suggest that low vitamin $\mathrm{D}$ levels may be a risk factor for respiratory tract infections in a number of non-SCI populations [9-12].

Members of our group previously studied a chronic SCI cohort between 1994 and 2005. We identified that neurologic level, severity, and duration of SCI were not associated with chest illness risk, but that self-reported wheeze, physiciandiagnosed chronic obstructive pulmonary disease (COPD), smoking history, decreased $\mathrm{FEV}_{1}$, and pneumonia/bronchitis since SCI were risk factors [13]. Given the potential importance of vitamin D as a determinant of respiratory health, we conducted the current study to assess whether longitudinal measurements of vitamin D levels were associated with increased risk of chest illness and to consider risk factors for chest illness identified in the prior study.

\section{Methods}

\section{Subjects}

Between August 2009 and August 2017, we recruited 361 persons with chronic SCI to assess factors associated with respiratory health. Participants were recruited from persons receiving care at Veterans Affairs (VA) Boston, including participants from our previous study of SCI and chest illness [13], from the greater Boston area through advertisement, and by mail to persons who received care at Spaulding Rehabilitation Hospital, Boston Medical Center, members of the National Spinal Cord Injury Association, and subscribers to New Mobility Magazine. Participants were eligible if they were 22 years old or older, one or more years following SCI, had no other reason for neuromuscular dysfunction, did not require ventilator support, and did not have a tracheostomy. Efforts were made to schedule subsequent visits one-and-a-half to two years apart. We excluded those without a detectable SCI level $(n=5)$, with history of stroke $(n=2)$, lung resections $(n=5)$, diagnosis of sarcoidosis $(n=1)$, incomplete data collection $(n=6)$, those unable to provide a blood sample during the initial study visit $(n=5)$, and those with only one study visit ( $n=$ 84). Following exclusions, 253 participants were included in the study. All 253 participants had one follow-up visit, 184 had two follow-up visits, and 108 had three follow-up visits for a total of 545 repeated assessments. There were 77 participants who had been included in our previous assessment of chest illness risk [13]. Spirometry data were unattainable for nine participants, therefore only 244 participants with 519 repeated assessments were included in analyses assessing associations with pulmonary function. The VA Boston Healthcare Institutional Review Board approved the protocol (IRB\# 2232, 2417, and 2751) and written informed consent was obtained. Participants were allowed to opt out of the study at any time and were provided with their vitamin $\mathrm{D}$ and pulmonary function test results to be discussed with their healthcare providers.

\section{Respiratory history and pulmonary function assessment}

A respiratory health questionnaire (ATS DLD-78) [14] with supplemental questions was completed at entry and updated at each subsequent encounter. The questionnaire was used to obtain a history of cigarette smoking, respiratory disease, and comorbid conditions that included diabetes, heart disease treated in the past 10 years, hypertension, COPD (emphysema or chronic bronchitis), asthma, and physiciandiagnosed pneumonia or bronchitis following SCI (after discharge following injury). As in the previous study [13], this questionnaire was also used to standardize the definition of a chest illness. At the baseline visit, we asked about a "chest illness that kept you off work, indoors at home, or in bed" for the prior one and three years. At each follow-up visit, the same question was used to assess chest illnesses since the previous visit. Participants were also asked whether each illness lasted a week or more, required contact with a physician, or whether antibiotic or bronchodilator medications were used. Pulmonary function was assessed by spirometry at baseline and at each follow-up visit [15], and the highest $\mathrm{FEV}_{1}$ and FVC values from acceptable efforts were used. Pulmonary medication use was defined as short acting bronchodilator use within $6 \mathrm{~h}$, long acting bronchodilator use within $24 \mathrm{~h}$, or any inhaled or oral steroid use at time of pulmonary function testing. Using the questionnaire to assess respiratory symptoms, any wheeze was defined as wheeze or whistling in the chest with a cold, occasionally apart from colds, or on most days or nights. Persistent wheeze was defined as wheezing with a cold and apart from colds or wheeze on most days or nights. Chronic cough was defined as cough on most days for three consecutive months, and chronic phlegm was defined similarly.

\section{Dual x-ray absorptiometry (DXA) for \% body fat}

At each visit we used a 5th generation GE Healthcare iDXA scanner to assess total and regional body composition using GE Lunar software analyzed by a certified clinical densitometrist (AAL) [16]. We assessed total percent body fat and percent trunk fat as previously described [17].

\section{Neurologic exam, stature, weight, and vitamin D analysis}

Motor level and completeness of injury were assessed by record review and exam and were based on the International 
Standards for Neurological Classification using the American Spinal Injury Association Impairment Scale (AIS) [18]. Participants were grouped into cervical motor complete (AIS A and B) and cervical AIS C, high thoracic (T1-T6) motor complete (AIS A and B) and AIS C, others with T7 or below motor complete (AIS A and B) and AIS C, and all others (AIS D). Height, weight, and body mass index (BMI) were assessed at baseline and at each follow-up visit $[15,17]$. Plasma 25-hydroxyvitamin $\mathrm{D}$ was measured at baseline and at each follow-up visit by high performance tandem mass spectrometry as previously described [15, 17].

\section{Statistical analyses}

Our primary outcome was number of chest illnesses reported between study visits. We used repeated measures negative binomial regression models fit as log-linear regressions with an offset option to adjust for follow-up duration to assess chest illness risk, and with an autoregressive covariance structure (PROC GENMOD, SAS 9.4; SAS Institute, Cary, NC). All potential risk factors (including vitamin D) at the beginning of each follow-up interval were used to assess subsequent risk at the next visit. We adjusted for history of smoking and COPD based on previous findings [13], as well as for age, sex, and chest illness history before study entry including pneumonia/ bronchitis after injury. We assessed vitamin $\mathrm{D}$ as a continuous covariate, in categories, and in quartiles, and we assessed SCI level, completeness of injury, and other covariates potentially associated with chest illness in the adjusted models. In additional multivariable models, we included measures of pulmonary function in place of COPD history. The intraclass correlation coefficient (ICC) was calculated to assess the consistency of vitamin D levels across each follow-up interval $[19,20]$.

\section{Results}

Mean age (standard deviation (SD)) and median injury duration (25th, 75th percentile) at study entry was 53.1 (13.7) years and $13.8(6.0,25.2)$ years, respectively (Table 1). A total of 208 participants $(82 \%)$ were men and $218(86 \%)$ were white. Most were AIS D $(n=97,38 \%), 59$ (23\%) had cervical motor complete (AIS A/B) or cervical AIS C SCI, 35 (14\%) had high thoracic (T1-T6) motor complete or high thoracic AIS C SCI, and $62(25 \%)$ had T7 or below motor complete and AIS C SCI. At study entry, 72 (29\%) participants were obese based on BMI categories (BMI > 30), 85 (34\%) were overweight (BMI 25-30), and $96(38 \%)$ were normal or underweight $(\mathrm{BMI}<25)$. Few participants were current smokers $(14 \%)$ at study entry. At the initial visit, vitamin D deficiency [21] $(<20 \mathrm{ng} / \mathrm{ml})$ was observed in $64(25 \%)$ participants while $131(52 \%)$ were insufficient (20 to $<30 \mathrm{ng} / \mathrm{ml}$ ), and $58(23 \%)$ had sufficient levels $(\geq 30 \mathrm{ng} / \mathrm{ml})$. Additional data on characteristics at study entry are provided in Supplementary Table 1.

The 253 participants contributed a total of 1107.4 personyears of follow-up. The median (25th, 75th percentile) duration of follow-up was $3.2(1.7,4.8)$ years (from 1.3 to 7.4 years) and persons were studied a median (25th, 75th percentile) of $1.7(1.5,2.1)$ years apart (from 1.1 to 6.0 years). Sixty participants reported 106 chest illnesses for an overall rate of 0.10 illness/person-year. Forty participants reported one illness and 20 reported two or more illnesses (Table 1). Of the 106 chest illnesses, $76 \%(n=81)$ were associated with phlegm, $83 \%(n=88)$ with cough, and $61 \%$ $(n=65)$ with wheeze. The majority of illnesses lasted more than one week $(n=86,81 \%)$ and resulted in a visit to a healthcare provider $(n=93,88 \%)$. Nearly half of participants who reported chest illnesses had at least one hospitalization as a result of an illness $(n=27,45 \%)$. The majority of those who reported a chest illness during the study also reported a history of pneumonia/bronchitis since injury $(n=42,70 \%)$. Participants who did not return for at least one follow-up visit compared with the 253 participants included in the study were similar in mean age (55.7 years compared with 53.1), baseline vitamin D level (25.4 ng/ml compared with 27.0), chest illness in the previous three years (24\% for both) and one year (12\% for both) before the baseline visit, or \%-predicted $\mathrm{FEV}_{1}$ (78\% compared to $76 \%$ ).

Assessment of the ICC indicated moderate correlation between vitamin $\mathrm{D}$ levels assessed at the beginning and the end of each follow-up interval [20]. The ICC was 0.59 $(95 \% \mathrm{CI}=0.51-0.67)$ between visits one and two, 0.63 $(95 \% \mathrm{CI}=0.54-0.71)$ between visits two and three, and $0.69(95 \% \mathrm{CI}=0.58-0.78)$ between visits three and four. Mean (SD) vitamin D level increased at each study visit, from $25.4(11.3) \mathrm{ng} / \mathrm{ml}$ at baseline, 28.7 (10.9) $\mathrm{ng} / \mathrm{ml}$ at visit two, and $31.4(12.4) \mathrm{ng} / \mathrm{ml}$ at visit three to $32.0(10.4) \mathrm{ng} / \mathrm{ml}$ at visit four. This increase was not due to participants with higher vitamin $\mathrm{D}$ levels selectively returning since mean (SD) vitamin D levels at study entry were similar for participants with one follow-up visit $(26.2(10.2) \mathrm{ng} / \mathrm{ml})$, two follow-up visits $(25.3(13.3) \mathrm{ng} / \mathrm{ml})$, or for those with three follow-up visits (25.1 (11.6) $\mathrm{ng} / \mathrm{ml})$. However, the percentage of participants reporting the use of vitamin D supplements at each study visit increased from $36 \%$ at baseline, $52 \%$ at visit two, $59 \%$ at visit three, to $61 \%$ at visit four.

In unadjusted analyses, there was no association between vitamin D level (assessed continuously, categorically, or in quartiles) and risk of future chest illness. For example, compared with participants with sufficient vitamin D levels ( $\geq 30 \mathrm{ng} / \mathrm{ml}$ ), persons with a deficient level $(<20 \mathrm{ng} / \mathrm{ml})$ had a RR $(95 \%$ CI) of $0.98(0.47,2.04)$. Season of vitamin D assessment and wheeze were not associated with risk. The 
Table 1 Characteristics of persons $(n=253)$ at study entry.

\begin{tabular}{|c|c|c|c|c|}
\hline & $\begin{array}{l}\text { Total persons } \\
n=253\end{array}$ & $\begin{array}{l}\text { Persons with chest } \\
\text { illnesses } \\
n=60^{\mathrm{h}}\end{array}$ & $\begin{array}{l}\text { Number of } \\
\text { illnesses }\end{array}$ & $\begin{array}{l}\text { Persons without } \\
\text { chest illnesses } \\
n=193\end{array}$ \\
\hline Age, years, mean (SD) & $53.1(13.7)$ & $54.5(13.0)$ & & $52.7(13.8)$ \\
\hline $\begin{array}{l}\text { Injury duration, median ( } 25 \text { th, } \\
75 \text { th percentile) }\end{array}$ & $13.8(6.0,25.2)$ & $14.1(6.8,25.3)$ & & $13.7(6.0,25.1)$ \\
\hline \multicolumn{5}{|l|}{$\operatorname{Sex}^{\mathrm{a}}$} \\
\hline Male & $208(82)$ & $43(72)$ & 73 & $165(86)$ \\
\hline Female & 45 (18) & $17(28)$ & 33 & $28(15)$ \\
\hline \multicolumn{5}{|l|}{ Race $^{\mathrm{a}}$} \\
\hline White & $218(86)$ & $52(87)$ & 93 & $166(86)$ \\
\hline Black & $24(10)$ & $7(12)$ & 12 & $17(9)$ \\
\hline Other $^{b}$ & $11(4)$ & $1(2)$ & 1 & $10(5)$ \\
\hline \multicolumn{5}{|l|}{ Vitamin $\mathrm{D}$, in categories $(\mathrm{ng} / \mathrm{ml})^{\mathrm{a}}$} \\
\hline$<20$ (deficient) & $64(25)$ & $15(25)$ & 23 & $49(25)$ \\
\hline 20 to $<30$ (insufficient) & $131(52)$ & $29(48)$ & 59 & $102(53)$ \\
\hline$\geq 30$ (sufficient) & $58(23)$ & $16(27)$ & 24 & $42(22)$ \\
\hline \multicolumn{5}{|l|}{ Vitamin $\mathrm{D}$, in quartiles $(\mathrm{ng} / \mathrm{ml})^{\mathrm{a}}$} \\
\hline$<19.9$ & $63(25)$ & $15(25)$ & 23 & $48(25)$ \\
\hline$\geq 19.9$ to $\leq 24.0$ & $64(25)$ & $16(27)$ & 28 & $48(25)$ \\
\hline$>24.0$ to $\leq 29.5$ & $63(25)$ & $12(20)$ & 30 & $51(26)$ \\
\hline$>29.5$ & $63(25)$ & $17(28)$ & 25 & $46(24)$ \\
\hline Vitamin $\mathrm{D}, \mathrm{ng} / \mathrm{ml}$ mean (SD) & $25.4(11.3)$ & $26.1(13.2)$ & & $25.2(11)$ \\
\hline \multicolumn{5}{|l|}{ Season $^{\mathrm{a}}$} \\
\hline Summer & $57(23)$ & $14(23)$ & 20 & $43(22)$ \\
\hline Fall & $59(23)$ & $12(20)$ & 21 & $47(24)$ \\
\hline Winter & $67(27)$ & $19(32)$ & 40 & $48(25)$ \\
\hline Spring & $70(28)$ & $15(25)$ & 25 & $55(29)$ \\
\hline Heart disease $^{\mathrm{a}}$ & 27 (18) & $10(17)$ & 14 & $17(9)$ \\
\hline $\mathrm{COPD}^{\mathrm{a}}$ & $21(8)$ & $8(13)$ & 15 & $13(7)$ \\
\hline Asthma $^{a}$ & $33(13)$ & $13(22)$ & 18 & $20(10)$ \\
\hline $\begin{array}{l}\text { Asthma or COPD (obstructive } \\
\text { lung disease) }{ }^{\mathrm{a}}\end{array}$ & 47 (19) & $18(30)$ & 30 & $29(15)$ \\
\hline Chronic cough ${ }^{\mathrm{a}}$ & $26(10)$ & $8(13)$ & 12 & $18(9)$ \\
\hline Chronic phlegm ${ }^{\mathrm{a}}$ & $37(15)$ & $9(15)$ & 22 & $28(15)$ \\
\hline Any wheeze ${ }^{a}$ & $113(45)$ & $33(55)$ & 58 & $80(42)$ \\
\hline Persistent wheeze ${ }^{a}$ & $46(18)$ & $14(23)$ & 26 & $32(17)$ \\
\hline Chest illness in the past year ${ }^{\mathrm{a}}$ & $29(12)$ & $13(22)$ & 33 & $16(8)$ \\
\hline Chest illness in the past 3 years ${ }^{a}$ & $61(24)$ & $26(43)$ & 52 & $35(18)$ \\
\hline $\begin{array}{l}\text { Pneumonia/bronchitis after } \\
\mathrm{SCl}^{\mathrm{a}}\end{array}$ & $120(47)$ & $42(70)$ & 81 & $78(40)$ \\
\hline \multicolumn{5}{|l|}{ Pneumonia/bronchitis after SCI ${ }^{\mathrm{a}}$} \\
\hline $\begin{array}{l}\text { Yes and with chest illness in } \\
\text { last } 3 \text { years }\end{array}$ & $40(16)$ & $21(35)$ & 44 & $19(10)$ \\
\hline $\begin{array}{l}\text { Yes and without chest } \\
\text { illness in last } 3 \text { years }\end{array}$ & $80(32)$ & $21(35)$ & 37 & $59(31)$ \\
\hline $\begin{array}{l}\text { No and with chest illness in } \\
\text { last } 3 \text { years }\end{array}$ & $21(8)$ & $5(8)$ & 8 & $16(8)$ \\
\hline
\end{tabular}


Table 1 (continued)

\begin{tabular}{|c|c|c|c|c|}
\hline & $\begin{array}{l}\text { Total persons } \\
n=253\end{array}$ & $\begin{array}{l}\text { Persons with chest } \\
\text { illnesses } \\
n=60^{\mathrm{h}}\end{array}$ & $\begin{array}{l}\text { Number of } \\
\text { illnesses }\end{array}$ & $\begin{array}{l}\text { Persons without } \\
\text { chest illnesses } \\
n=193\end{array}$ \\
\hline \multicolumn{5}{|l|}{ BMI, in categories $\left(\mathrm{kg} / \mathrm{m}^{2}\right)^{\mathrm{a}}$} \\
\hline$>30$ (obese) & $72(29)$ & $19(32)$ & 35 & $53(28)$ \\
\hline 25-30 (overweight) & $85(34)$ & $21(35)$ & 38 & $64(33)$ \\
\hline $\begin{array}{l}<25 \text { (normal or } \\
\left.\text { underweight }^{\mathrm{c}}\right)\end{array}$ & $96(38)$ & $20(33)$ & 33 & $76(39)$ \\
\hline BMI, kg/m², mean (SD) & $27.1(6)$ & $27.6(6)$ & & $26.9(6)$ \\
\hline$\%$-Trunk fat, mean (SD) & $39.5(11)$ & $40.9(10)$ & & $39.1(11)$ \\
\hline$\%$-Total body fat, mean (SD) & $36.4(9)$ & $37.9(9)$ & & $35.9(9)$ \\
\hline \multicolumn{5}{|l|}{ Cigarette use $\mathrm{e}^{\mathrm{a}}$} \\
\hline Current & $36(14)$ & $6(10)$ & 9 & $30(16)$ \\
\hline Former & $103(41)$ & $25(42)$ & 56 & $78(40)$ \\
\hline Never & $114(46)$ & $29(48)$ & 41 & $85(44)$ \\
\hline \multicolumn{5}{|l|}{ SCI classification ${ }^{\mathrm{a}}$} \\
\hline $\begin{array}{l}\text { Motor complete cervical and } \\
\text { AIS C } C^{d}\end{array}$ & $59(23)$ & $16(27)$ & 27 & $43(22)$ \\
\hline $\begin{array}{l}\text { Motor complete high } \\
\text { thoracic(T1-T6) and AIS C }\end{array}$ & $35(14)$ & $7(12)$ & 8 & $28(15)$ \\
\hline $\begin{array}{l}\text { Other motor complete and } \\
\text { AIS } C^{\mathrm{f}}\end{array}$ & $62(25)$ & $10(17)$ & 12 & $52(27)$ \\
\hline \multirow[t]{2}{*}{ All AIS D } & $97(38)$ & $27(45)$ & 59 & $70(36)$ \\
\hline & $n=244$ & $n=58$ & & $n=186$ \\
\hline \multicolumn{5}{|l|}{$\mathrm{FEV}_{1} / \mathrm{FVC}^{\mathrm{a}, \mathrm{g}}$} \\
\hline$\leq 0.70$ & $53(22)$ & $17(29)$ & 29 & $36(19)$ \\
\hline$>0.70$ & $191(78)$ & $41(71)$ & 75 & $150(81)$ \\
\hline $\mathrm{FEV}_{1} / \mathrm{FVC}(\mathrm{SD})^{\mathrm{g}}$ & $0.77(0.11)$ & $0.74(0.11)$ & & $0.78(0.10)$ \\
\hline$\%$-Predicted $\mathrm{FEV}_{1}$, mean $(\mathrm{SD})^{\mathrm{g}}$ & $78.17(20.41)$ & $72.42(22.98)$ & & $79.96(19.26)$ \\
\hline$\%$-Predicted FVC, mean $(\mathrm{SD})^{\mathrm{g}}$ & $78.93(19.24)$ & $76.09(21.23)$ & & $79.82(18.54)$ \\
\hline Pulmonary medicine use $\mathrm{a}^{\mathrm{a}, \mathrm{g}}$ & $16(7)$ & $10(17)$ & 18 & $6(3)$ \\
\hline
\end{tabular}

${ }^{\mathrm{a}} n(\%)$

$\mathrm{b}_{2}$ American Indian, 2 Asian, 7 Hispanic/Latino

${ }^{\mathrm{c}}$ Underweight: $<18.5 \mathrm{~kg} / \mathrm{m}^{2}, n=13$

${ }^{\mathrm{d}} 15$ AIS $\mathrm{C}$ with a total of 2 chest illnesses

${ }^{e} 3$ AIS $\mathrm{C}$ with a total of 1 chest illness

${ }^{\mathrm{f}} 10$ AIS $\mathrm{C}$ with a total of 1 chest illness

$\mathrm{g}_{n}=244$

h40 had 1 illness, 11 had 2 illnesses, 3 had 3 illnesses, 3 had 4 illnesses, 1 had 5 illnesses, 1 had 7 illnesses, 1 had 11 illnesses

strongest association with chest illness risk in unadjusted analyses was history of pneumonia/bronchitis after SCI stratified by whether or not a chest illness was reported in the three years before study entry (Supplementary Table 2).

In adjusted models that included age, sex, smoking history, COPD history, and pneumonia/bronchitis since SCI stratified by report of a chest illness in the three years before study entry (Table 2), persons with a deficient vitamin D level $(<20 \mathrm{ng} / \mathrm{ml})$ had a higher risk of future chest illness compared with persons with sufficient levels $(\geq 30 \mathrm{ng} / \mathrm{ml})$ but with wide confidence limits that include $1.0(\mathrm{RR}=1.36$, $95 \% \mathrm{CI}=0.74,2.47)$. When participants in the lowest vitamin D quartile $(<19.9 \mathrm{ng} / \mathrm{ml})$ were compared with the highest quartile, the RR was similarly increased $(\mathrm{RR}=$ $1.41,95 \% \mathrm{CI}=0.78,2.53)$. The risk with insufficient levels $(20$ to $<30 \mathrm{ng} / \mathrm{ml})$ was not increased $(\mathrm{RR}=0.90,95 \% \mathrm{CI}=$ $0.51,1.60)$. With vitamin $\mathrm{D}$ assessed continuously, per $20 \mathrm{ng} / \mathrm{ml}$ increase, a higher concentration of vitamin D was 
Table 2 Associations with chest illness after study entry $(n=253)^{\mathrm{a}}$.

\begin{tabular}{|c|c|c|c|}
\hline Characteristic & Relative Risk & $95 \% \mathrm{CI}$ & $P$ value \\
\hline \multicolumn{4}{|l|}{ Vitamin D categories (ng/ml) } \\
\hline \multicolumn{4}{|l|}{ Pneumonia/bronchitis after SCI } \\
\hline $\begin{array}{l}\text { Yes and with chest illness } \\
\text { in last } 3 \text { years }\end{array}$ & 7.62 & $3.70,15.71$ & $<0.001$ \\
\hline $\begin{array}{l}\text { Yes and without chest } \\
\text { illness in last } 3 \text { years }\end{array}$ & 2.75 & $1.26,5.99$ & 0.01 \\
\hline $\begin{array}{l}\text { No and with chest illness } \\
\text { last } 3 \text { years }\end{array}$ & 1.93 & $0.70,5.34$ & 0.21 \\
\hline \multicolumn{4}{|l|}{ Vitamin D (ng/ml) } \\
\hline$<20$ (deficient) & 1.36 & $0.74,2.47$ & 0.32 \\
\hline$\geq 20$ to $<30$ (insufficient) & 0.90 & $0.51,1.60$ & 0.72 \\
\hline$\geq 30$ (sufficient) & Ref & Ref & Ref \\
\hline \multicolumn{4}{|l|}{ Vitamin D quartiles (ng/ml) } \\
\hline \multicolumn{4}{|l|}{ Pneumonia/bronchitis after SCI } \\
\hline $\begin{array}{l}\text { Yes and with chest illness } \\
\text { in last } 3 \text { years }\end{array}$ & 7.46 & $3.62,15.38$ & $<0.001$ \\
\hline $\begin{array}{l}\text { Yes and without chest } \\
\text { illness in last } 3 \text { years }\end{array}$ & 2.76 & $1.27,5.98$ & 0.01 \\
\hline $\begin{array}{l}\text { No and with chest illness } \\
\text { last } 3 \text { years }\end{array}$ & 1.89 & $0.68,5.25$ & 0.22 \\
\hline \multicolumn{4}{|l|}{ Vitamin D (ng/ml) } \\
\hline$<19.9$ & 1.41 & $0.78,2.53$ & 0.25 \\
\hline$\geq 19.9$ to $\leq 24.0$ & 1.11 & $0.55,2.25$ & 0.77 \\
\hline$>24.0$ to $\leq 29.5$ & 0.76 & $0.36,1.61$ & 0.48 \\
\hline$>29.5$ & Ref & Ref & Ref \\
\hline \multicolumn{4}{|l|}{ Vitamin D continuous (ng/ml) } \\
\hline \multicolumn{4}{|l|}{ Pneumonia/bronchitis after SCI } \\
\hline $\begin{array}{l}\text { Yes and with chest illness } \\
\text { in last } 3 \text { years }\end{array}$ & 7.57 & $3.69,15.53$ & $<0.001$ \\
\hline $\begin{array}{l}\text { Yes and without chest } \\
\text { illness in last } 3 \text { years }\end{array}$ & 2.73 & $1.27,5.88$ & 0.01 \\
\hline $\begin{array}{l}\text { No and with chest illness } \\
\text { last } 3 \text { years }\end{array}$ & 2.00 & $0.73,5.51$ & 0.18 \\
\hline Vitamin D per $20 \mathrm{ng} / \mathrm{ml}$ & 0.70 & $0.44,1.12$ & 0.14 \\
\hline
\end{tabular}

${ }^{a}$ All models age, sex, smoking history, COPD history, and past chest illness adjusted

associated with a reduction in risk $(\mathrm{RR}=0.70,95 \% \mathrm{CI}=$ $0.44,1.12$; equivalent to a $30 \%$ reduction). The strongest risk factor for future chest illness was a history of pneumonia/bronchitis since SCI and report of a chest illness in the three years before entry (RR 7.62, 95\% CI $=3.70$, 15.71). Even in participants who did not report a chest illness in three years before entry, pneumonia/bronchitis since SCI was associated with an increased future chest illness risk (Table 2).

Results were similarly suggestive in participants who completed pulmonary function testing $(n=244)$ (Table 3$)$. Adjusting for age, sex, smoking history, past chest illness, and lower $\mathrm{FEV}_{1} / \mathrm{FVC}$, a deficient vitamin D level $(<20 \mathrm{ng} / \mathrm{ml})$ was associated with future chest illness $(\mathrm{RR}=1.18,95 \% \mathrm{CI}=$
$0.63,2.21)$ as was the lowest vitamin $\mathrm{D}$ quartile compared with the highest quartile $(\mathrm{RR}=1.21,95 \% \mathrm{CI}=0.66,2.23)$. With vitamin D assessed continuously, per $20 \mathrm{ng} / \mathrm{ml}$ increase, a higher concentration of vitamin $\mathrm{D}$ was also associated with a reduction in risk $(\mathrm{RR}=0.74,95 \% \mathrm{CI}=0.47,1.17$, equivalent to a $26 \%$ reduction). A greater $\mathrm{FEV}_{1} / \mathrm{FVC}$ was associated with reduced chest illness risk for every $\mathrm{SD}$ increase $(\mathrm{RR}=0.80$, $95 \% \mathrm{CI}=0.65,0.99$ ) (Table 3). In similar models, \%-predicted FVC was not associated with chest illness, but there was a suggestive association between a greater \%-predicted $\mathrm{FEV}_{1}$ and reduced chest illness risk for every SD increase $(\mathrm{RR}=0.92,95 \% \mathrm{CI}=0.67,1.26)$ (Table 3 ).

In a sensitivity analysis, we assessed other covariates potentially associated with future chest illness in adjusted models in Table 2. These included injury duration, trunk and total body fat, BMI, season, heart disease history, asthma history, respiratory symptoms (chronic cough, chronic phlegm, any wheeze, and persistent wheeze) and SCI injury/completeness. There was no meaningful effect on the RR associated with vitamin D by including these covariates (Supplementary Table 3). In addition, injury duration (Supplementary Table 4) and tetraplegia (cervical AIS A/B and cervical AIS C) compared with AIS D (Supplementary Table 5) remained unassociated with chest illness risk. All participants with motor complete SCI had a lower chest illness risk compared with the AIS D reference group.

\section{Discussion}

We found a suggestive association between plasma vitamin $\mathrm{D}$ level and future chest illness in participants with chronic SCI. We used common categories for vitamin D deficiency, insufficiency, and sufficiency as these are most likely to be used clinically [21] and also assessed vitamin D continuously and by quartile. Although the confidence intervals were wide, each analysis provided similar results. Although imprecise, participants in the lowest quartile and with deficient vitamin D levels had the highest associations with chest illness, and chest illness risk decreased with greater vitamin D concentrations. A history of previous chest illness, particularly in persons with pneumonia/bronchitis after SCI, had the strongest association with future chest illness with the greatest association in persons who also reported chest illness in the three years before study entry. A decreased $\mathrm{FEV}_{1} / \mathrm{FVC}$, consistent with airflow obstruction, was also associated with chest illness risk, with suggestive effect of \%-predicted $\mathrm{FEV}_{1}$. In contrast to our previous study, wheeze was not associated with future chest illness. We also did not find that injury duration, higher neurologic level, or more complete SCI increased chest illness risk. 
Table 3 Age, sex, and smoking history-adjusted risk of reporting a chest illness, including the characteristics listed for each model $(n=244)$.

\begin{tabular}{|c|c|c|c|}
\hline Characteristic & Relative risk & $95 \% \mathrm{CI}$ & $P$ value \\
\hline \multicolumn{4}{|c|}{ Past chest illness, $\mathrm{FEV}_{1} / \mathrm{FVC}$, vitamin $\mathrm{D}$ in categories } \\
\hline \multicolumn{4}{|l|}{ Pneumonia/Bronchitis since SCI } \\
\hline $\begin{array}{l}\text { Yes and with chest illness in last } \\
3 \text { years }\end{array}$ & 7.16 & $3.22,15.92$ & $<0.001$ \\
\hline $\begin{array}{l}\text { Yes and without chest illness in last } \\
3 \text { years }\end{array}$ & 2.69 & $1.21,5.98$ & 0.02 \\
\hline No and with chest illness last 3 years & 1.56 & $0.49,4.99$ & 0.45 \\
\hline \multicolumn{4}{|l|}{ Vitamin D (ng/ml) } \\
\hline$<20$ (deficient) & 1.18 & $0.63,2.21$ & 0.60 \\
\hline$\geq 20$ to $<30$ (insufficient) & 1.01 & $0.60,1.69$ & 0.97 \\
\hline$\geq 30$ (sufficient) & Ref & Ref & Ref \\
\hline $\mathrm{FEV}_{1} / \mathrm{FVC}($ per $\mathrm{SD}=0.10)$ & 0.80 & $0.65,0.99$ & 0.04 \\
\hline \multicolumn{4}{|c|}{ Past chest illness (not shown), $\mathrm{FEV}_{1} / \mathrm{FVC}$, vitamin $\mathrm{D}$ in quartiles } \\
\hline \multicolumn{4}{|l|}{ Vitamin D (ng/ml) } \\
\hline$<19.9$ & 1.21 & $0.66,2.23$ & 0.54 \\
\hline$\geq 19.9$ to $\leq 24.0$ & 1.18 & $0.61,2.28$ & 0.62 \\
\hline$>24.0$ to $\leq 29.5$ & 0.88 & $0.45,1.74$ & 0.72 \\
\hline$>29.5$ & Ref & Ref & Ref \\
\hline $\mathrm{FEV}_{1} / \mathrm{FVC}($ per $\mathrm{SD}=0.10)$ & 0.80 & $0.65,0.99$ & 0.04 \\
\hline \multicolumn{4}{|c|}{ Past chest illness (not shown), $\mathrm{FEV}_{1} / \mathrm{FVC}$, vitamin $\mathrm{D}$ continuous } \\
\hline Vitamin D per $20 \mathrm{ng} / \mathrm{ml}$ & 0.74 & $0.47,1.17$ & 0.20 \\
\hline $\mathrm{FEV}_{1} / \mathrm{FVC}($ per $\mathrm{SD}=0.10)$ & 0.81 & $0.65,1.00$ & 0.05 \\
\hline \multicolumn{4}{|c|}{ Past chest illness, \%-predicted $\mathrm{FEV}_{1}$, vitamin $\mathrm{D}$ in categories } \\
\hline \multicolumn{4}{|l|}{ Pneumonia/Bronchitis since SCI } \\
\hline $\begin{array}{l}\text { Yes and with chest illness in last } \\
3 \text { years }\end{array}$ & 7.51 & $3.10,18.17$ & $<0.001$ \\
\hline $\begin{array}{l}\text { Yes and without chest illness in last } \\
3 \text { years }\end{array}$ & 2.63 & $1.16,5.97$ & 0.02 \\
\hline No and with chest illness last 3 years & 1.71 & $0.54,5.40$ & 0.36 \\
\hline \multicolumn{4}{|l|}{ Vitamin D (ng/ml) } \\
\hline$<20$ (deficient) & 1.18 & $0.62,2.24$ & 0.62 \\
\hline$\geq 20$ to $<30$ (insufficient) & 1.00 & $0.60,1.66$ & 1.00 \\
\hline$\geq 30$ (sufficient) & Ref & Ref & Ref \\
\hline$\%$-predicted $\mathrm{FEV}_{1}($ per SD $=20.4)$ & 0.92 & $0.67,1.26$ & 0.60 \\
\hline
\end{tabular}

Past chest illness (not shown), \%-predicted $\mathrm{FEV}_{1}$, vitamin $\mathrm{D}$ in quartiles Vitamin D (ng/ml)

$\begin{array}{llll}<19.9 & 1.21 & 0.64,2.27 & 0.56 \\ \geq 19.9 \text { to } \leq 24 & 1.19 & 0.61,2.33 & 0.61 \\ >24.0 \text { to } \leq 29.5 & 0.85 & 0.44,1.65 & 0.63 \\ >29.5 & \text { Ref } & \text { Ref } & \text { Ref } \\ \text { o-predicted } \text { FEV }_{1}(\text { per } \mathrm{SD}=20.4) & 0.93 & 0.68,1.28 & 0.67\end{array}$

Past chest illness (not shown), \%-predicted $\mathbf{F E V}_{1}$, vitamin D continuous

$\begin{array}{llll}\text { Vitamin D per } 20 \mathrm{ng} / \mathrm{ml} & 0.74 & 0.47,1.17 & 0.20\end{array}$

$\%$-predicted $\mathrm{FEV}_{1}($ per SD = 20.4) $\quad 0.92 \quad 0.68,1.25 \quad 0.60$

Past chest illness, \%-predicted FVC, vitamin D in categories

Pneumonia/Bronchitis since SCI

\begin{tabular}{|c|c|c|c|}
\hline $\begin{array}{l}\text { Yes and with chest illness in last } \\
3 \text { years }\end{array}$ & 8.12 & $3.48,18.97$ & $<0.00$ \\
\hline $\begin{array}{l}\text { Yes and without chest illness in last } \\
3 \text { years }\end{array}$ & 2.89 & $1.28,6.51$ & 0.01 \\
\hline $\begin{array}{l}\text { No and with chest illness last } 3 \text { years } \\
\text { tamin } D(n g / m l)\end{array}$ & 1.64 & $0.55,4.92$ & 0.38 \\
\hline$<20$ (deficient) & 1.17 & $0.63,2.18$ & 0.62 \\
\hline$\geq 20$ to $<30$ (insufficient) & 1.02 & $0.61,1.70$ & 0.94 \\
\hline$\geq 30$ (sufficient) & Ref & Ref & Ref \\
\hline -predicted FVC (per SD $=19.1)$ & 1.02 & $0.75,1.40$ & 0.88 \\
\hline
\end{tabular}

\%-predicted FVC (per SD = 19.1) $\quad 1.02 \quad 0.75,1.40 \quad 0.88$
Table 3 (continued)

\begin{tabular}{|c|c|c|c|}
\hline Characteristic & Relative risk & $95 \% \mathrm{CI}$ & $P$ value \\
\hline \multicolumn{4}{|c|}{ Past chest illness (not shown), \%-predicted FVC, vitamin D in quartiles } \\
\hline \multicolumn{4}{|l|}{ Vitamin D (ng/ml) } \\
\hline$<19.9$ & 1.20 & $0.65,2.20$ & 0.56 \\
\hline$\geq 19.9$ to $\leq 24.0$ & 1.22 & $0.62,2.39$ & 0.56 \\
\hline$>24.0$ to $\leq 29.5$ & 0.86 & $0.44,1.69$ & 0.66 \\
\hline$>29.5$ & Ref & Ref & Ref \\
\hline$\%$-predicted FVC (per SD = 19.1) & 1.04 & $0.76,1.43$ & 0.81 \\
\hline \multicolumn{4}{|c|}{ Past chest illness (not shown), \%-predicted FVC, vitamin D continuous } \\
\hline Vitamin D per $20 \mathrm{ng} / \mathrm{ml}$ & 0.74 & $0.47,1.17$ & 0.20 \\
\hline$\%$-predicted FVC (per SD $=19.1)$ & 1.02 & $0.76,1.39$ & 0.88 \\
\hline
\end{tabular}

Our results regarding vitamin $\mathrm{D}$ are consistent with several prior cohort and larger prospective studies in non-SCI populations which report a positive association between low vitamin D levels and an increased risk of acute respiratory infection. Laaksi found levels $<40$ nanomoles/liter (nmol/l) (equivalent to $16 \mathrm{ng} / \mathrm{ml}$ ) in young male Finnish military recruits were associated with more days absent from duty due to respiratory illness [9]. Jovanovich found that vitamin D levels $<37 \mathrm{nmol} / 1$ (equivalent to $<14.8 \mathrm{ng} / \mathrm{ml}$ ) were associated with increased risk of hospitalization for community acquired pneumonia [10]. Sabetta found that vitamin D levels $>38 \mathrm{ng} / \mathrm{ml}$ during winter months resulted in a twofold decrease in risk of acute viral respiratory illnesses in a small cohort of 195 healthy adults followed during a winter season [11]. A large cross-sectional study of data collected through the National Health and Nutrition Examination Survey from 2001 to 2006 also showed that in healthy US adults vitamin $D$ levels were inversely associated with the odds of an acute respiratory illness (up to levels of $\sim 30 \mathrm{ng} / \mathrm{ml}$ ) [12]. While each of these studies found an inverse association between vitamin D levels and respiratory illnesses, they were limited by short duration of follow-up, often on the order of months. Our study, which utilized a repeated measures assessment over multiple follow-up visits, supports these findings.

Results from randomized trials on the impact of vitamin D supplementation on respiratory illness have had both positive and null findings [22-25]. These studies were heterogenous in regards to study population, baseline vitamin D, replacement strategies, and levels reported following the intervention. However, trials which demonstrated an association with reduced chest illness risk tended to have participants with lower mean vitamin D levels at enrollment and more participants with sufficient levels following intervention. Therefore, it is possible that the effect of vitamin $\mathrm{D}$ on potentially reducing respiratory illnesses risk may be in persons with the lowest vitamin D levels. Lehouck studied the effect of vitamin D supplements in persons with moderate-severe COPD via a randomized, single-center, double-blind, placebo-controlled trial and 
showed the subgroup with the lowest baseline vitamin D levels $(<10 \mathrm{ng} / \mathrm{ml})$ had a statistically significant reduction in exacerbations over one year [26]. In a meta-analysis of 25 randomized control trials, a subgroup analysis found vitamin D supplementation provided protection from acute respiratory illnesses in persons with low levels $(<25 \mathrm{nmol} / \mathrm{l}$, equivalent to $10 \mathrm{ng} / \mathrm{ml}$ ) [27]. These findings align with our results which suggest that deficient levels $(<20 \mathrm{ng} / \mathrm{ml})$ are most associated with future chest illness.

Our study has several limitations. We assessed chest illness based on self-report and as an illness that resulted in time off work, indoors, or in bed. Chest illnesses that did not interfere with daily activities or were not recalled were not included in the analysis, and we were unable to distinguish between lower and upper respiratory illnesses. Our study included some persons who participated in a previous 1994-2005 study assessing chest illness risk [13]; however, upon entry to the current study new baseline and follow-up data were obtained. Though we broadly recruited from the greater Boston area, the persons included in our study may not fully represent the target population of outpatient persons with chronic SCI. There is likely a survivor bias in our assessment as we excluded those with the most severe sequela from SCI, those who did not survive the first year after injury, and participants had to be well enough to attend a study visit and survive to participate in the most recent cohort. While there was large proportion of participants who did not return for all study visits, baseline characteristics of those participants did not differ from those who did return; however, it is possible that other factors in those who did not return may have impacted our findings had they remained enrolled. While we did not provide vitamin D supplementation as part of our study, the proportion of participants independently taking vitamin D supplements increased over the study period likely due to the increased clinical awareness of vitamin D deficiency. This may have reduced our ability to detect a stronger effect of vitamin D levels on chest illness. The change in mean vitamin $\mathrm{D}$ levels and supplementation use over the follow-up period demonstrates the importance of assessing these factors longitudinally.

Strengths of our study include the standardized assessment of participants and the repeated assessment of plasma vitamin $\mathrm{D}$ level and other personal risk factors, including pulmonary function, with 545 assessments. Our study observed a chest illness rate of 0.10 illness/person-year which is similar to the rate observed in our prior SCI chest illness study (0.12) [13]. A study by Smith et al. using VA SCI outpatient records assessing upper respiratory infections, lower respiratory tract infections, and pneumonia and influenza reported a similar rate of $\sim 0.10$ respiratory illnesses/person-year [1], suggesting that rates of illnesses in our study are similar to those seen in persons with SCI in outpatient settings. The continued finding of the association of future chest illness with previous chest illness history and with reduced pulmonary function reinforces the validity of our findings and suggests that these characteristics may be used clinically to identify persons with chronic SCI who are most at risk for developing future chest illness. These findings are similar to results reported in persons without SCI but with COPD and asthma where the greatest risk factor for a future exacerbation was prior exacerbation $[28,29]$. Like asthma and COPD, there appears to be a subset of persons with SCI with a previous chest illness who are more likely to experience future chest illness, independent of their pulmonary function.

\section{Conclusion}

A reduction in plasma vitamin $\mathrm{D}$ level may be associated with increased risk of chest illness in participants with chronic SCI, particularly in persons with deficient levels. Future chest illness risk was also associated with prior chest illness history and reduction in pulmonary function. Clinical awareness of these associations may contribute to the clinical management of individuals with SCI in recognizing persons at most risk for chest illnesses.

\section{Data availability}

The data for this study are archived at VA Boston Healthcare System and are not publicly available per Department of Veterans Affairs information privacy rules.

Acknowledgements We thank Antonio A. Lazzari, MD, CCD, PhD, and Samuel Davis, Boston VA Healthcare System, technician, for DXA data collection. We appreciate the participation of veterans at VA Boston and others from the greater Boston area with chronic SCI.

Funding This study was funded by VA Rehabilitation Research and Development Merit Review Grants B6618R and I01 RX000792 from the US Department of Veterans Affairs Rehabilitation Research and Development Service; and NIH NIAMS Grant R01 AR059270. The contents do not represent the views of the US Department of Veterans Affairs or the United States Government.

Author contributions EG, AAL, CGT, and JEH contributed to study conception and design. MT, RLG, EG, DRG, and KC were responsible for data analysis with review and interpretation by CGT, JEH, and AAL. $\mathrm{KC}, \mathrm{RLG}$, and EG were responsible for the draft manuscript. All authors contributed to editing and approved the final manuscript.

\section{Compliance with ethical standards}

Ethical statement Informed written consent was obtained from all volunteers who participated in this study. The Institutional Review Board at VA Boston Healthcare System approved the protocol (IRB \# 2232,2417 , and 2751). We certify that all applicable institutional and governmental regulations concerning the ethical use of human volunteers were followed during the course of this research. 
Conflict of interest The authors declare that they have no conflict of interest.

Publisher's note Springer Nature remains neutral with regard to jurisdictional claims in published maps and institutional affiliations.

\section{References}

1. Smith BM, Evans CT, Kurichi JE, Weaver FM, Patel N, Burns SP. Acute respiratory tract infection visits of veterans with spinal cord injuries and disorders: rates, trends, and risk factors. J Spinal Cord Med. 2007;30:355-61.

2. National spinal cord injury statistical center facts and figures at a glance. Birmingham, AL: University of Alabama at Birmingham; 2018.

3. Berlowitz DJ, Wadsworth B, Ross J. Respiratory problems and management in people with spinal cord injury. Breathe. 2016;12: 328-40.

4. Brown R, DiMarco AF, Hoit JD, Garshick E. Respiratory dysfunction and management in spinal cord injury. Respiratory Care. 2006;51:853-70.

5. Zosky GR, Berry LJ, Elliot JG, James AL, Gorman S, Hart PH. Vitamin D deficiency causes deficits in lung function and alters lung structure. Am J Respir Crit Care Med. 2011;183:1336-43.

6. Pfeffer PE, Hawrylowicz CM. Vitamin D and lung disease. Thorax. 2012;67:1018-20.

7. Flueck JL, Perret C. Vitamin D deficiency in individuals with a spinal cord injury: a literature review. Spinal Cord. 2017;55:428-34.

8. Koutrakis NE, Goldstein RL, Walia P, Polak MM, Lazzari AA, Tun CG, et al. Vitamin D, diet, and lifestyle in a chronic SCI population. Spinal Cord. 2019;57:117-27.

9. Laaksi I, Ruohola JP, Tuohimaa P, Auvinen A, Haataja R, Pihlajamäki $\mathrm{H}$, et al. An association of serum vitamin $\mathrm{D}$ concentrations $<40 \mathrm{nmol} / \mathrm{L}$ with acute respiratory tract infection in young Finnish men. Am J Clin Nutr. 2007;86:714-7.

10. Jovanovich AJ, Ginde AA, Holmen J, Jablonski K, Allyn RL, Kendrick J, et al. Vitamin D level and risk of community-acquired pneumonia and sepsis. Nutrients. 2014;6:2196-205.

11. Sabetta JR, DePetrillo P, Cipriani RJ, Smardin J, Burns LA, Landry ML. Serum 25-hydroxyvitamin D and the incidence of acute viral respiratory tract infections in healthy adults. PLoS ONE. 2010;5. https://doi.org/10.1371/journal.pone.0011088.

12. Monlezun DJ, Bittner EA, Christopher KB, Camargo CA, Quraishi SA. Vitamin D status and acute respiratory infection: cross sectional results from the United States National Health and Nutrition Examination Survey, 2001-2006. Nutrients. 2015;7:1933-44.

13. Stolzmann KL, Gagnon DR, Brown R, Tun CG, Garshick E. Risk factors for chest illness in chronic spinal cord injury. Am J Phys Med Rehabil. 2010;89:576-83.

14. Ferris BG. Epidemiology Standardization Project (American Thoracic Society). Am Rev Respir Dis. 1978;118:1-120.

15. Garshick E, Walia P, Goldstein RL, Teylan MA, Lazzari AA, Tun $\mathrm{CG}$, et al. Associations between vitamin D and pulmonary function in chronic spinal cord injury. J Spinal Cord Med. 2018;0:1-7.
16. Shepherd JA, Fan B, Lu Y, Wu XP, Wacker WK, Ergun DL, et al. A multinational study to develop universal standardization of wholebody bone density and composition using GE Healthcare Lunar and Hologic DXA systems. J Bone Min Res. 2012;27:2208-16.

17. Walia P, Goldstein RL, Teylan M, Lazzari AA, Hart JE, Tun CG, et al. Associations between vitamin $\mathrm{D}$, adiposity, and respiratory symptoms in chronic spinal cord injury. J Spinal Cord Med. 2017;41:667-75.

18. Kirshblum SC, Waring W, Biering-Sorensen F, Burns SP, Johansen M, Schmidt-Read M, et al. Reference for the 2011 revision of the international standards for neurological classification of spinal cord injury. J Spinal Cord Med. 2011; 34:547-54.

19. Hankinson SE, Manson JE, Spiegelman D, Willett WC, Longcope C, Speizer FE. Reproducibility of plasma hormone levels in postmenopausal women over a 2-3-year period. Cancer Epidemiol Biomark Prev. 1995;4:649-54.

20. Hertzmark E and Spiegelman D. The SAS ICC9 Macro. https://cdn1.sph.harvard.edu/wp-content/uploads/sites/271/2012/ 09/icc9.pdf. 2010.

21. Holick MF, Binkley NC, Bischoff-Ferrari HA, Gordon CM, Hanley DA, Heaney RP, et al. Evaluation, treatment, and prevention of vitamin D deficiency: an Endocrine Society clinical practice guideline. J Clin Endocrinol Metab. 2011;96: 1911-30.

22. Murdoch DR, Slow S, Chambers ST, Jennings LC, Stewart AW, Priest PC, et al. Effect of vitamin D3 supplementation on upper respiratory tract infections in healthy adults: the VIDARIS randomized controlled trial. JAMA. 2012;308:1333-9.

23. Laaksi I, Ruohola J-P, Mattila V, Auvinen A, Ylikomi T, Pihlajamäki H. Vitamin D supplementation for the prevention of acute respiratory tract infection: a randomized, double-blinded trial among young Finnish men. J Infect Dis. 2010;202:809-14.

24. Ginde AA, Blatchford P, Breese K, Zarrabi L, Linnebur SA, Wallace JI, et al. High dose monthly vitamin D for prevention of acute respiratory infection in older long-term care residents: a randomized clinical trial. J Am Geriatr Soc. 2017;65:496-503.

25. Camargo CA Jr, Ganmaa D, Frazier AL, Kirchberg FF, Stuart JJ, Kleinman K, et al. Randomized trial of vitamin D supplementation and risk of acute respiratory infection in Mongolia. Pediatrics. 2012;130:e561-7.

26. Lehouck A, Mathieu C, Carremans C, Baeke F, Verhaegen J, Van Eldere J, et al. High doses of vitamin D to reduce exacerbations in chronic obstructive pulmonary disease: a randomized trial. Ann Intern Med. 2012;156:105-14.

27. Martineau AR, Jolliffe DA, Hooper RL, Greenberg L, Aloia JF, Bergman $\mathrm{P}$, et al. Vitamin D supplementation to prevent acute respiratory tract infections: systematic review and meta-analysis of individual participant data. BMJ. 2017;356:16583.

28. Hurst JR, Vestbo J, Anzueto A, Locantore N, Müllerova H, TalSinger R, et al. Susceptibility to exacerbation in chronic obstructive pulmonary disease. N. Engl J Med. 2010;363:1128-38.

29. Miller MK, Lee JH, Miller DP, Wenzel SE, TENOR Study Group. Recent asthma exacerbations: a key predictor of future exacerbations. Respir Med. 2007;101:481-9. 